\title{
ANTIMICROBIAL ACTIVITY OF SUGARBEET PHYLLOSPHERIC MICROORGANISMS AGAINST CERCOSPORA BETICOLA SACC.
}

\author{
ELASSIUTY, M. ELHAMY ${ }^{1}$, M. A. RIZK ${ }^{2}$ AND A. E. IBRAHIM ${ }^{2}$ \\ 1. Plant Path. Res. Inst., ARC, Giza \\ 2. Fac. Sci., Cairo Univ., Giza
}

(Manuscript received 8 October 2009)

\begin{abstract}
Screening some epiphytic microorganisms isolated from the phyllosphere of sugar beet plants for their potential antagonism against Cercospora beticola revealed a high potency of one isolate of each of Pseudomonas fluorescens, P.aureginosa, Bacillus subtilis, Streptomyces albidoflavus, S.lavandulae and $S$. griseoviridis. One isolate of P.putida showed moderate inhibitory effect. Among fungi, one isolate of Trichoderma harzianum exhibited moderate inhibitory activity. Some isolates were weak inhibitors. Isolates were evaluated for their ability to elaborate secondary metabolites, such as HCN, IAA, siderophores, and some hydrolytic enzymes such as chitinase, lipase, pectinase, protease and cellulose.
\end{abstract}

\section{INTRODUCTION}

Sugar beet (Beta vulgaris L.) is the second important sugar crop in Egypt after sugar cane in terms of acreage, total production and cash value. The cercospora leaf spot caused by Cercospora beticola is the most serious foliar disease, in Egypt, as in most of sugar beet growing area of the world. The traditional means to control this destructive disease is applying the harmful fungicides, however, using biological agents is encouraged at the time being. Many of previous investigators succeeded in reducing infection with leaf spot diseases of different crops by using some bioagents (Harman, 2006). Kiewnick and Jacobson (1998), reported the possibility of controlling cercospora leaf spot by Bacillus subtilis isolated from sugar beet phyllosphere.

The present investigation was carried out to isolate some antagonistic epiphytic microorganisms against C.beticola from the phyllosphere of sugar beet . Identification of these potent organisms and their antagonistic action were also evaluated.

\section{MATERIAL AND METHODS}

\section{Isolation of epiphytic microorganisms from leaves of sugar beet plants}

Leaf samples were collected from sugar beet-growing fields, at Shinno village, Kafr El-Sheikh governorate in 2006/2007 growing season. Samples were taken from healthy plants adjacent to cercospora-infected ones and immediately transferred to the Lab. in an ice chest for isolation. Leaf subsamples (10 g each) were washed in tap 
water and transferred to $100 \mathrm{ml}$ of sterilized distilled water in $250 \mathrm{ml}$-flasks. Flasks were shaken at $120 \mathrm{rpm}$ for one hour. Thereafter, serial 10-fold dilutions were prepared and $1 \mathrm{ml}$ of each dilution was seeded into $250 \mathrm{ml}$ from each of specific media., Bacillus spp. were recovered after pasteurization using nutrient agar. King's medium B was used for isolating fluorescent pseudomonads, Martin's medium for fungi and starch nitrate agar, starch caseinate agar and glycerol-yeast extract agar for isolating actinomycetes. Plates were incubated at $30 \mathrm{C}$ and four replicate plates of each of the respective media were used for each group. Pure cultures were grown on agar slants and kept at $10{ }^{\circ} \mathrm{C}$ till use.

\section{Screening for potential antagonists}

The recovered microorganisms were screened for their potency in inhibiting the growth of C.beticola. The pathogen was seeded into test agar media (17g agar/L). Spore suspension from C.beticola was prepared at the concentration of $10^{6}$ in sterilized distilled water, from which $1 \mathrm{ml}$ was introduced into the prepared media at the rate of $1 \mathrm{ml}$ per $200 \mathrm{ml}$ in 250 conical flasks of PDA, nutrient agar, King B \& starch nitrate prepared for testing fungi, Bacillus spp., Pseudomonas spp. and actinomycetes, respectively. Plates were surface inoculated with the test organisms $(0.5 \mathrm{~cm}$ diam. discs for fungi and actinomycetes), and heavily charged loop for bacteria, at the center of the agar plates, then incubated at $30{ }^{\circ} \mathrm{C}$. Four replicate plates were used for each treatment and the antagonist-free media acted as control. Inhibition zones around the tested antagonists were measured after 3 days for bacteria and 5-8 days for fungi and actinomycetes. The diameter of inhibition zones was measured and means of replicates were calculated and indexed as low, moderate and high degree of antagonistic potential.

\section{Identification of selected bioagents}

Fungi were identified according to cultural characteristics and microscopic examination. Pseudomonas spp.were identified following the analytical purified identification system (API $20 \mathrm{E}$ ). Bacillus spp. were identified by a combination of API $20 \mathrm{E}$ and API CH strips as described by Borsodi, et al.(2007). Actinomycetes were identified according to their morphological characters (pigments, color of mycelium and spores), resistance to antibiotics, and biochemical tests (Williams et al.,1983).

\section{Metabolic by-products}

The selected isolates were screened for production of hydrogen cyanide (HCN), indole acetic acid (IAA), siderophores, and some extracellular hydrolytic enzymes as described below: 


\section{HCN production}

Bacteria (48h-old culture) were streaked on slant of Luria Bertani agar medium (LB), triptone $10 \mathrm{~g}$, yeast extract $5 \mathrm{~g}, \mathrm{NaCl} 5 \mathrm{~g}$, agar $15 \mathrm{~g}$ \& distilled water $1 \mathrm{~L}$, amended with glycine $(4.4 \mathrm{gl} / 1)$. Sterilized filter paper were soaked in $0.5 \%(\mathrm{w} / \mathrm{v})$ picric acid in $1 \% \mathrm{Na}_{2} \mathrm{CO}_{3}$ and hanged with the plug inside the tubes. After incubation at $28 \pm 1^{\circ} \mathrm{C}$, changing color of the hanging filter paper from yellow to brown, due the evolved HCN indicated a positive reaction.

\section{Production of IAA}

In vitro method was used for screening isolates for their ability to produce indole acetic acid (IAA) and the analogous products. Isolates were grown on Luria Bertani (LB) amended with $5 \mathrm{mM}$ 1-tryptophan that was overlaid with an 82-mmdiameter nitrocellulose membrane disk. Agar plates were inoculated with bacterial cultures and incubated at $28{ }^{\circ} \mathrm{C}$ for 3 days. The membranes were overlaid with a Whatman No2 filter paper saturated with Salkowski reagent. Microorganisms producing IAA or analogous compounds exhibit a characteristic pink to red color after 0.5 to $3 \mathrm{~h}$ on the filter surface.

\section{Production of Siderophores}

Siderophore production was estimated on the universal medium, chromoazurols (CAS) agar medium (sodium carbonate \& ferric chloride). Bacterial inocula were spotted on the CAS agar medium and plates were incubated at $28 \pm 1^{\circ} \mathrm{C}$ for $48 \mathrm{~h}$. Development of pink color around the bacterial colony indicates positive reaction.

\section{In vitro assay of some extracellular hydrolytic enzymes}

The activities of extracellular hydrolytic enzymes were detected on plate-based assays by streaking bacterial culture on the medium containing enzyme substrate and measuring the clearing zones of the degraded substrate around the bacterial colonies after incubation period of 5 days at $25 \pm 1 \mathrm{C}$.

Agar base $(1.8 \% \mathrm{w} / \mathrm{v})$ was used for studying hydrolytic enzymes . Plates enriched with either of $5 \%$ skim milk, $0.2 \%$ tween 80 or $0.5 \%$ carboxymethyl cellulose, and citrus pectin were used for detecting the production of protease, lipase, cellulose and pectinase, respectively. Plates were examined for hydrolysis as judged by clearing area around the inocula. However, lipase activity was visualized as green color formed after adding 20\% copper sulfate solution.

Chitinase activity was examined by adding colloidal chitin as substrate to the basal medium and incubation for 7 days at $25 \mathrm{C}$. Clear zone around the inocula indicates the positive reaction. 


\section{RESULTS}

\section{Isolation of epiphytic microorganisms from leaves of sugar beet plants}

A number of six different fungal species were recovered from the phyllosphere of sugar beet leaves. Aspergillus spp. were isolated in the highest frequency (8 isolates) followed by Penicillium spp. (7 isolates). Other fungal species, namely, Mucor spp., Alternaria spp., Fusarium spp. were recovered at low frequencies (2, 4, and 3 isolates, respectively). Trichoderma sp., occasionally appeared at a very low frequency (1sp.). The fluorescent pseudomonads appeared on the isolation plates at very high frequencies (12 isolates). Six isolates of Bacillus spp., were recovered in the isolating plates. Regarding actinomycetes, a number of 14 different isolates were recovered.

\section{Antagonism of the isolated microorganisms}

Results (Table 1), indicate that one out of the 8 isolates of Aspergillus spp. (12.5 \%) showed low antagonistic effect against C.beticola. The remaining recovered fungal isolates, except Trichoderma sp. have no antagonistic potential, while Trichoderma sp. efficiently inhibited the growth of the pathogen causing moderate degree of antagonism.

Results showed that 2 out of 6 Bacillus spp. isolates (33.3\%) effectively inhibited the growth of the pathogen. Bacillus sp. $\left(B_{1}\right)$ showed a high degree of antagonism, while, $B_{4}$ was less effective (low degree) against the pathogen. The fluorescent pseudomonads, however, actively antagonized the growth of C.beticola, where 4 isolates $(33.3 \%)$ could efficiently affect growth of the pathogen. The degree of the antagonism against the pathogen differ from low $\left(\mathrm{Sp}_{4}\right)$, moderate $\left(\mathrm{Sp}_{1}\right)$ to high $\left(\mathrm{Sp}_{2} \& \mathrm{Sp}_{6}\right)$ as shown in Table 1 .

Concerning the actinomycetes, 5 out of the14 candidates (35.7\%) could affect the growth of the pathogen. Three of these isolates efficiently affected the fungal growth causing a high degree of antagonism. These are isolates No. Act , $_{2} \&_{5}$ ), whereas, isolates No.8 $\&_{11}$ showed low effect against the pathogen (Table 1 ). 
Table 1. Antimicrobial activity of isolated microorganisms in inhibiting the mycelial growth of C. beticola

\begin{tabular}{|c|c|c|c|c|}
\hline \multirow{2}{*}{ Microorganism } & \multicolumn{3}{|c|}{ Inhibition zone $(\mathrm{mm}) /$ on } & \multirow{2}{*}{$\begin{array}{l}\text { Degree of } \\
\text { antagonism }\end{array}$} \\
\hline & Potato Dextrose Agar & King's medium $B$ & Starch nitrate media & \\
\hline Aspergillus sp.* & 6 & - & - & Low $* *$ \\
\hline Trichoderma sp. & 9 & - & - & Moderate \\
\hline Pseudomonas sp.(Ps 1$)$ & 7 & 9 & - & Moderate \\
\hline Pseudomonas sp. $\left(\mathrm{Ps}_{2}\right)$ & 13 & 17 & - & High \\
\hline Pseudomonas sp. $\left(\mathrm{Ps}_{4}\right)$ & - & 3 & - & Low \\
\hline Pseudomonas sp.(PS 6$)$ & 16 & 20 & - & High \\
\hline Bacillus sp.(B1) & 17 & 13 & - & High \\
\hline Bacillus sp. (B4) & 6 & 6 & - & low \\
\hline Actinomycete $\left(\right.$ Act $\left._{1}\right)$ & 20 & - & 21 & High \\
\hline Actinomycete $\left(\right.$ Act $\left._{2}\right)$ & 16 & - & 20 & High \\
\hline Actinomycete $\left(\right.$ Act $\left._{5}\right)$ & 15 & - & 15 & High \\
\hline Actinomycete $\left(\mathrm{Act}_{8}\right)$ & 5 & - & 6 & Low \\
\hline Actinomycete $\left(\right.$ Act $\left._{11}\right)$ & 6 & - & 6 & Low \\
\hline
\end{tabular}

*Specific names are shown in Table (2)

** Low degree $=$ diameter mean up to $6 \mathrm{~mm}$, moderate degree $=$ diameter mean from 7 to $12 \mathrm{~mm}$, high degree $=$ diameter mean above $12 \mathrm{~mm}$.

\section{Identification of the recovered epiphytic organisms}

The promising microbial isolates that showed potent effect against the target pathogen, in addition to some other candidates were subjected to identification according to the methods described under Material \& Methods.

Bacillus spp., were identified using a combination of the API 20E and API $50 \mathrm{CH}$ strips of the analytical purified identification system. They were identified as $B$. subtilis $\left(\mathrm{B}_{1}\right)$ and B.pumilus $\left(\mathrm{B}_{4}\right)$ as shown in Table 2.

Fluorescent pseudomonads, were identified by using the system of API20E, in addition to some complementary test as described in Bergey's Manual of Determinative Bacteriology (2006). Oxidase, nitrate reductase, growth at $41^{\circ} \mathrm{C}$, fluorescent pigments on King`s medium B, blood agar haemolysis ...etc (Table 2).

For actinomycetes, the Probabilistic Identification Matrix developed by Williams et al. (1983) was followed. Isolates No.Act $1, \mathrm{Act}_{2}, \mathrm{Act}_{5}, \mathrm{Act}_{8} \& \mathrm{Act}_{11}$ were identified as Streptomyces albidoflavus (Act $\left.{ }_{1}\right)$,S.lavandulae (Act $\left.{ }_{2}\right)$, S.griseoviridis (Act $\left.{ }_{5}\right)$, S.purpureus $\left(\mathrm{Act}_{8}\right)$ and $S$. rimosus $\left(\mathrm{Act}_{11}\right)$, respectively. 
The fungal isolate of Trichoderma sp. was identified according to culture characters and microscopic examination as T. harzianum.

\section{Major metabolic byproducts produced by the isolated microorganisms}

Production of secondary metabolites by the epiphytic organisms under study that may regulate their antagonistic mechanisms are shown in Table 2. Indole acetic acid (IAA) was produced by some of the fluorescent pseudomonads (Table 2). These are P.putida $\left(\mathrm{Ps}_{1} \& \mathrm{Ps}_{10}\right)$, P.fluoroscens $\left(\mathrm{Ps}_{4} \& \mathrm{Ps}_{7}\right)$. Most of Pseudomonas spp. under study were found to have the potential to produce hydrogen cyanide HCN, however, at different degrees ( + to +++ ) according to the appearance of yellowish to brownish color on filter paper as described under Material \& Methods (Table 2).

Regarding the production of siderophores, it was found that six out of the twelve screened pseudomonads were able to produce compounds which react with ferric chloride producing pink color around colonies as described previously. These are P.putida $\left(\mathrm{Ps}_{1}\right)$, P.fluoroscens $\left(\mathrm{Ps}_{2}\right)$, P. sp. $\left(\mathrm{Ps}_{3}\right)$, P.fluoroscens $\left(\mathrm{Ps}_{4}\right)$, P. aureginosa $\left(\mathrm{Ps}_{6}\right)$ \& P. sp. $\left(\mathrm{Ps}_{9}\right)$ (Table 2). Some organisms produced the hydrolytic enzymes, as chitinase, lipase, pectinase, protease and cellulase on nutrient agar (Table 2). Only Trichoderma sp., was able to produce chitinase. Lipase was readily produced by six isolates of actinomycetes (S.albidoflavus Act ${ }_{1}$, S. Lavandulae Act ${ }_{2}$, S. griseoviridis Act $_{5}$, S. purpureus $\mathrm{Act}_{8}$ and $S$. rimosus $\mathrm{Act}_{11} \& \mathrm{Act}_{12}$ ). Pseudomonas spp. isolate $\mathrm{Ps}_{2}$ and $\mathrm{Ps}_{7}$ as well as Bacillus spp. isolates $B_{1}$ and $B_{4}$ actively produced lipase. With respect to pectinase and cellulase, they were only produced by Bacillus spp. $\left(B_{1}, B_{4}\right)$ and Trichoderma sp. $\left(\operatorname{Tr}_{1}\right)$. Protease produced by Pseudomonas sp. $\left(\mathrm{Ps}_{7}\right)$, by 3 isolates of Bacillus spp. ( $\left.\mathrm{B}_{1}, \mathrm{~B}_{2} \& \mathrm{~B}_{4}\right)$ and 5 isolates of actinomycetes (Act $1, \mathrm{Act}_{2}, \mathrm{Act}_{5}, \mathrm{Act}_{9} \&$ Act $\left._{13}\right)$ 
Table 2. Characterization of the metabolic by-products and identification of microorganisms

\begin{tabular}{|c|c|c|c|c|c|c|c|c|c|c|}
\hline \multirow{2}{*}{ Group } & \multirow{2}{*}{$\begin{array}{c}\text { Test } \\
\text { Organism }\end{array}$} & \multirow{2}{*}{$\begin{array}{c}\text { Inhibition zone } \\
\text { (Antagonism) }\end{array}$} & \multirow{2}{*}{$\begin{array}{c}\text { IAA } \\
\text { production }\end{array}$} & \multirow{2}{*}{$\begin{array}{c}\mathrm{HCN} \\
\text { Production }\end{array}$} & \multirow{2}{*}{$\begin{array}{c}\text { Siderophore } \\
\text { Production }\end{array}$} & \multicolumn{5}{|c|}{ Enzyme activity } \\
\hline & & & & & & Chitinase & Lipase & Pectinase & Proteases & Cellulase \\
\hline \multirow{12}{*}{$\begin{array}{c}\text { Pseudomonas } \\
\text { Isolates } \\
\text { (Fluorescent form) }\end{array}$} & P. putida $\left(\mathrm{PS}_{1}\right)$ & + & + & ++ & + & - & - & - & - & - \\
\hline & P. fluorescens $\left(\mathrm{PS}_{2}\right)$ & + & - & + & + & - & + & - & - & - \\
\hline & P. sp. $\left(\mathrm{PS}_{3}\right)$ & - & - & - & + & - & - & - & - & - \\
\hline & P. fluorescens $\left(\mathrm{PS}_{4}\right)$ & + & + & ++ & + & - & - & - & - & - \\
\hline & P. sp. $\left(\mathrm{PS}_{5}\right)$ & - & - & + & - & - & - & - & - & - \\
\hline & P. aureginosa $\left(\mathrm{PS}_{6}\right)$ & + & - & ++ & + & - & - & - & - & - \\
\hline & P. fluorescens $\left(\mathrm{PS}_{7}\right)$ & - & + & +++ & - & - & + & - & + & - \\
\hline & P. sp. $\left(\mathrm{PS}_{8}\right)$ & - & - & + & - & - & - & - & - & - \\
\hline & P. sp. $\left(\mathrm{PS}_{9}\right)$ & - & - & - & - & - & - & - & - & - \\
\hline & P. putida $\left(\mathrm{PS}_{10}\right)$ & - & + & +++ & + & - & - & - & - & - \\
\hline & P. sp. $\left(\mathrm{PS}_{11}\right)$ & - & - & - & - & - & - & - & - & - \\
\hline & P. sp. $\left(\mathrm{PS}_{12}\right)$ & - & - & - & - & - & - & - & - & - \\
\hline \multirow{6}{*}{$\begin{array}{l}\text { Bacillus } \\
\text { spp. }\end{array}$} & B. subtilis $\left(B_{1}\right)$ & + & - & - & - & - & + & + & + & + \\
\hline & B. sp. $\left(B_{2}\right)$ & - & - & - & - & - & + & + & + & - \\
\hline & B. sp. $\left(B_{3}\right)$ & - & - & - & - & - & - & - & - & - \\
\hline & B. Pumilus $\left(\mathrm{B}_{4}\right)$ & + & - & - & - & - & + & - & + & - \\
\hline & B. sp. $\left(B_{5}\right)$ & - & - & - & - & - & - & - & - & - \\
\hline & B. sp. $\left(\mathrm{B}_{6}\right)$ & - & - & - & - & - & - & - & - & - \\
\hline \multirow{14}{*}{ Actinomycetes } & S. albidoflavus ( Act $_{1}$ ) & + & - & - & - & - & + & - & + & - \\
\hline & $\begin{array}{c}\text { S. lavendulae } \\
\quad\left(\mathrm{Act}_{2}\right)\end{array}$ & + & - & - & - & - & + & - & + & - \\
\hline & $\mathrm{Act}_{3}$ & - & - & - & - & - & - & - & - & - \\
\hline & $\mathrm{Act}_{4}$ & - & - & - & - & - & - & - & - & - \\
\hline & S. griseoviridis $\left(\right.$ Act $_{5}$ ) & + & - & - & - & - & + & - & + & - \\
\hline & $\mathrm{Act}_{6}$ & - & - & - & - & - & - & - & - & - \\
\hline & $\mathrm{Act}_{7}$ & - & - & - & - & - & - & - & - & - \\
\hline & S. purpureus (Act 8 ) & + & - & - & - & - & + & - & - & - \\
\hline & $\mathrm{Act}_{9}$ & - & - & - & - & - & - & - & + & - \\
\hline & $\mathrm{Act}_{10}$ & - & - & - & - & - & - & - & - & - \\
\hline & $\begin{array}{l}\text { S. rimosus } \\
\left(\text { Act }_{11}\right)\end{array}$ & + & - & - & - & - & + & - & - & - \\
\hline & Act $_{12}$ & - & - & - & - & - & + & - & - & - \\
\hline & Act $_{13}$ & - & - & - & - & - & - & - & + & - \\
\hline & Act $_{14}$ & - & - & - & - & - & - & - & - & - \\
\hline \multirow[t]{2}{*}{ Fungi } & $\begin{array}{c}\text { Trichoderma harzianum } \\
\left(\mathrm{Tr}_{1}\right)\end{array}$ & + & - & - & - & + & - & + & - & + \\
\hline & Aspergillus niger. & + & - & - & - & - & - & - & - & - \\
\hline
\end{tabular}




\section{DISCUSSION}

A total of 57 different microbial isolate were recovered from the surface of sugar beet leaves collected from fields of Kafr El-Sheikh governorate. Screening for the antagonistic potential toward Cercospora beticola was carried out in vitro. Various isolated candidates were capable of antagonizing the target pathogen. This can be due mainly to the ability of these organisms to produce metabolic by-products in the growing media that affect the pathogen. Based on the evidences accumulated on the low sensitivity of fungi to many naturally produced antibiotics, with exception of gliotoxin, other by-products were considered in this work. The production of secondary metabolites as volatile substances, lytic enzymes, plant auxins, HCN and siderophores were looked upon with great concern. Two filamentous fungi (Aspergillus niger \& Trichoderma harzianum), two Bacillus spp. (B.subtilis \& B.bumilus), four Pseudomonas spp. (1 isolate of P.putida, 2 of P.fluorescens \& 1 of P.aureginosa) and five actinomycetes (Streptomyces albidoflavus, S. lavendulae, S .griseoviridis, S. purpureus \& S. rimosus) were found to inhibit the growth of C.beticola. Several previous investigations emphasized that B.subtilis, Trichoderma spp., actinomycetes and Pseudomonas pp. can antagonize and suppress many target pathogens in the Lab. (ElAssiuty et al., 1986, Ahmadzadeh and Sharifi-Tehrani, 2009). The antagonistic effects of these microbes are attributed to the production of antibiotics in growing media. In addition to the action of hyperparasitism of T.harzianum, it has the potential to produce an extracellular antibiotic, namely, gliotoxin. Gliotoxin is produced by numerous fungi, including Trichoderma spp. (Howell and Stipanovic, 1983). This compound possesses a broad spectrum of activity against fungi and bacteria. It inhibits protein and nucleic acid synthesis as reported by Kerridge (1958). T.harzianum could suppress the radial growth of Acremonium strictum (syn. Cephalosporium acremonium) in vitro and control acremonium wilt of grain sorghum under greenhouse conditions (El-Assiuty et al., 1986).

It is known that many actinomycetes have a broad spectrum of biological activities. In addition, the production of some volatile substances has been reported in Streptomyces spp. and other species (Dickschat et al., 2005). Hence, the efficiency of actinomycetes recovered in the present study may be attributed to the production of a variety of secondary metabolites in the growing media.

Most microbial isolates having inhibitory effect against C.beticola, in addition to some other isolates, were identified and screened for their ability to produce some metabolites and lytic enzymes responsible for the antimicrobial activity in the Lab. Plant auxin, indole acetic acid (IAA) was produced only by four Pseudomonas spp. 
These are $\mathrm{Ps}_{1}, \mathrm{Ps}_{2}, \mathrm{Ps}_{4} \& \mathrm{Ps}_{6}$. Many of the antagonistic agents belonging to fluorescent pseudomonads as well as some Bacillus spp. release metabolites that directly stimulate growth of many plants and improving its qualitative characters beside the major role of these microflora in biological control for many plant diseases. Recently, IAA has been shown to inhibit the growth of plant associated pathogens (Liu and Nester, 2006). Parmar and Dadarwal(2000) reported that P. fluorescens Pf-5, P. fluorescens 279, P. fluorescens isolated from rhizosphere and phyllosphere of various field crops, could stimulate plant growth and suppress plant pathogens.

Hydrogen cyanide (HCN) is produced by P.fluorescens (Voisard et al., 1989). P.putida $\left(\mathrm{Ps}_{1} \& \mathrm{Ps}_{10}\right)$ and $P$. aureginosa $\left(\mathrm{Ps}_{6}\right)$ were also able to produce this metabolite, which may contribute to the potential of the bacterial strains to suppress the growth of the target pathogen. Qualitative detection of the presence of $\mathrm{HCN}$ in the culture media indicated that amounts produced differ greatly from one strain to another as judged by the intensity of the brown color. Strain No.7 \&10 produced higher amounts of HCN compared to the others. However, these two isolates were not among those showing inhibitory potential indicating that HCN may not be the sole factor involved. Voisard et al. (1989) emphasized that HCN production by Pseudomonas strain CHAO contributes to the suppression of black root of tobacco. It is anticipated that HCN producers of Pseudomonas spp. under study could act as biocontrol agent towards cercospora leaf spot of sugar beet.

Production of siderophores was detected in six cultures of Pseudomonas spp. Siderophores are expressed as a high ability to chelate iron and create a biocontrol action through sequestering iron from pathogens, thus limiting their growth. Fluorescent pseudomonads are considered to be an excellent example for siderophore producers through the action of its fluorescent pigments, pyoverdines or pseudobactins under iron deficiency. Siderophores produced by strains of Pseudomonas spp., are considered as a constituent of biological products for plant disease control, and hence the bacterium could be safely employed for this purpose.

Results of hydrolytic enzymes indicated that some of the studied microorganisms were active producers of such extracellular enzymes. Production of hydrolytic enzymes by microorganisms is frequently involved in the attack of phytopathogenic fungi (Picard et al., 2000). Chitinase was found to be excreted only by T.harzianum. It was suggested that efficiency of the bioagent in inhibiting growth of the pathogen and, in turn, controlling plant disease is attributed mainly to the excretion of chitinases that play an important role in biodegrading the cell wall of the pathogen. Some Trichoderma isolates were evaluated by Galletti et al. (2008) as possible biological control agents for the control of cercospora leaf spot. 
An array of hydrolytic enzymes are known to be produced by some microorganisms causing perforations in the cell wall that may also lead to the release of chitinase by the antagonist that weakens the cell wall and increases the permeability of fungal cells, which assist in turn the penetration by the mycoparasite as suggested by Rousseau et al. (1996) and Lewis et al. (1991).

Among the studied microorganisms, Bacillus sbtilis ( $B_{1}$ produced lipase, protease, pectinase and cellulase. Likewise, Trichoderma harzianum produced chitinase, pectinase and cellulase. These results indicate that $B$. subtilis $\left(B_{1}\right)$ and T.harzianum are promising organisms for further studies.

In conclusion, epiphytic phyllospheric microorganisms recovered from leaves of sugar beet can be promising agents for controlling cercospora leaf spot. Further study will be made to utilize these promising isolates either singly or in combination, on sugar beet plants for the control of cercospora leaf spot in the field.

\section{REFERENCES}

1. Ahmadzadeh, M. and A. Sharifi-Tehrani. 2009. Evaluation of fluorescent pseudomonads for plant growth promotion, antifungal activity against Rhizoctonia solani on common bean andbiocontrol potential. Biological control, 48: 101- 107.

2. Brenner, D. J., N. R., Krieg, J. Staley and G. M. Garritty. 2006. Bergey's Manual of Systematic Bacteriology, Second Edition.

3. Borsodi A. K., J. Makk, A. Rusznyák, B. Vajna, G. Taba and K. Márialigeti. 2007. Phenotypic characterization and molecular taxonomic studies on Bacillus and related isolates from Phragmites australis periphyton. Aquatic Botany, 86: 243252.

4. Dickschat, J., S. Martens, T. Brinkhoff, T.M. Simon and S. Schulz. 2005. Volatiles released by a Streptomyces species isolated from the North sea. Chemistry and Biodiversity, 2: 837-865.

5. El-Assiuty, E.M., T.H. Abd-El-Moity and H.A. El-Shafey. 1986. Mycoparasitic effect of Trichoderma harzianum Rifai against Cephalosporium acremonium Corda. Egypt. J.Microbiol., 21: 111-116.

6. Galletti, S., P.L. Burzi, C. Cerato, S. Marinello and E. Sala. 2008. Trichoderma as a potential biocontrol agent for Cercospora leaf spot of sugar beet. Biocontrol., 53(6): 917-930.

7. Harman, GE. 2006. Overview of mechanisms and uses of Trichoderma spp. Phytopathology, 96: 190-194. 
8. Howell, C.R. and R.D. Stipanovic. 1983. Gliovirin, a new antibiotic from Gliocladium virens, and its role in the biological control of Pythium ultimum. Canadian J.Microbiology. 29: 321-324.

9. Kerridge, D. 1958. The effect of actidione and other antifungal agents on nucleic acid and protein synthesis in Saccharomyces carlsbergensis. J. General Microbiology. 19: 497-506.

10. Kiewnick, S. and B.J. Jacobsen. 1998. Biological control of Cercospora beticola on sugar beet with phyllosphere bacteria. Molecular Approaches in Biological Control: IOBC Bulletin, 21: 279-282.

11. Lewis, J.A. D.P. Roberts and M.D. Hollenbeck. 1991. Induction of ytoplasmic leakage from Rhizoctonia solanli hyphae by Gliocladium virens and partial characterization of leakage factor. Biocontrol Science and Technology, 1: 21-29.

12. Liu,P. and E.W. Nester. 2006. Indole acetic acid, a product of transferred DNA, inhibits virgin expression and growth of Agrobacterium tumefaciens C58. Proc. Natl. Acad. Sci. USA 12: 4658-4662.

13. Parmar, N. and K.R. Dadarwal. 2000. Stimulation of plant growth of chickpea by inoculation of fluorescent pseudomonads. J. Appl. Microbiol., 86: 36-44.

14. Picard, K., Y. Tirilly and N. Benhamou. 2000. Cytological effects of cellulases in the parasitism of Phytophthora parasitica by Pythium oligandrum. Applied and Environmental Microbiology, 66: 4305-4314.

15. Rousseau, A. N. Benhamou, I. Chet and Y. Piche. 1996. Mycparasitism of extramaterial phase of Glumus intaradices by Trichoderma harzianum. Phytopathology, 86: 434-443.

16. Singh, P. P., Y. C. Shin, C. S. Park and Y.R. Chung. 1999. Biological control of Fusarium wilt of cucumber by chitinolytic bacteria. Phytopathology, 89: 92-99.

17. Voisard, C. C. Keel, D. Haas and G. Defago. 1989. Cyanide production by Pseudomonas fluorescens helps suppress black root of tobacco under gnotobiotic conditions. EMBO J., 8: 351-358.

18. Williams, S. T., M. Goodfellow, E. M. H. Wellington, J.C. Vickers, G.Alderson and P.H.A.Sneath. 1983. A Probability Matrix for Identification of some Streptomycetes. J. Gen. Microbiol., 129: 1815-1830. 


\section{القررة التضادية للكائنات الدقيقة من المحيط الورقى لبنجر السكر \\ فى تثبيط سيركوسبورا بيتيكولا}

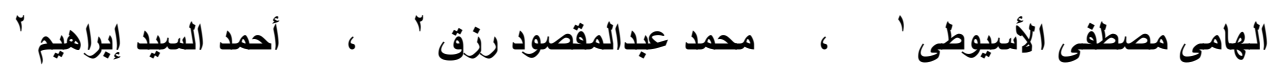

$$
\text { r ا . . معهد بحوث أمراض النباتات - مركز البحوث الزراعية - جيزة. }
$$

تتاولت الدراسـة عزل الكائنات الدقيقة من السطح الورقى لبنجر السكر بغرض دراسـة قدرتها

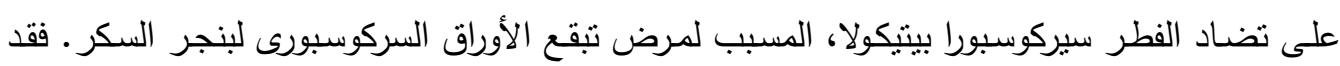

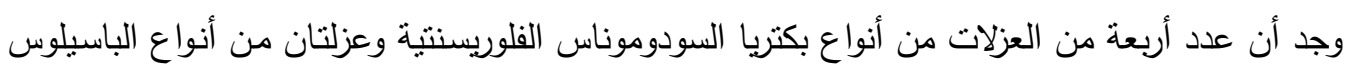

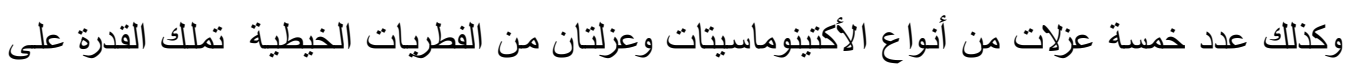

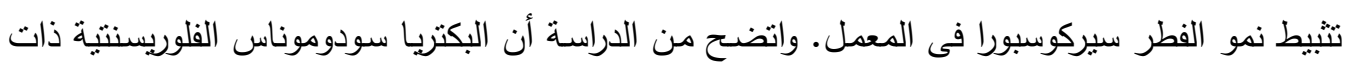

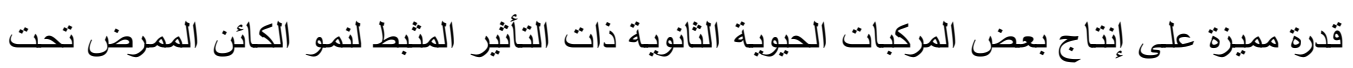

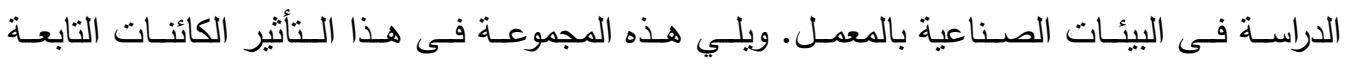

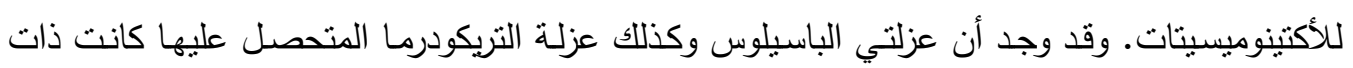

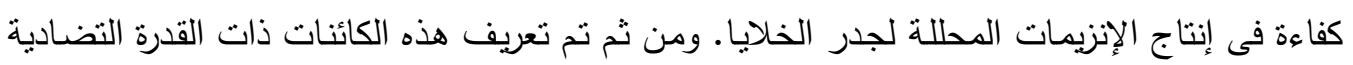
معمليا. وقد أمكن تعريف الميكروبات المضادة على النحو النالى :

Pseudomonas spp., P.putida, P.fluorescens and P.aureginosa.

Bacillus spp., B.subtilis and B.pumilus

Streptomyces, S.albidoflavus, S.lavendulae, S.griseoviridis, S.purpureus and S. rimosus 